to the harpoons of antler and bone previously found in Scotland at Oban, Oronsay and Kirkcudbright. The present find is figured in The Times of December 13.

\section{Indian Cultural Studies at Oxford}

WHrLE the range and character of the collections of the India Museum at South Kensington will always give London a predominant position as a centre of Indian cultural studies, it should not be overlooked that the University of Oxford is not unconscious of its obligations in this direction. The report of the curators of the Indian Institute for the academic year $1937-38$ states that during this period the museum has undergone a much-needed reorganization, thanks to a substantial grant from the Max Müller Memorial Fund and a generous gift from Mr. and Mrs. Spalding. The aim of the reorganization is not only to raise the character of the exhibits, but also to serve the needs of the studies carried on in the Institute, and more especially to stimulate interest in the antiquities and art of India. Among gifts and bequests, upon which the museum has to rely to a large extent, recent additions include a Buddhist shrine on loan from Mrs. Alexander Scott, which shows excellent specimens of the work of Newari and Tibetan artists, while Dr. Stella Kramrisch has lent a valuable collection of Hindu sculpture. Some interesting terra-cottas have come from the Royal Asiatic Society, and a collection of Siamese sculpture, the property of Dr. Reginald Le May, is especially instructive as a demonstration of the influence of Indian art and civilization on southeastern Asia. Further facilities for the study of the cultural relations of south-eastern Asia will also be afforded members of the University by the valuable collection of Malayan books formed by Mr. W. W. Skeat, author of "Malay Magic", and, with Dr. C. Otto Blagdon, of "Pagan Tribes of the Malay Peninsula". This collection has been accepted by the University as a gift from Captain W. Ogilvy, by whom they were purchased for that purpose. Volumes additional to those purchased have been added by Mr. Skeat in order to enhance the value of the collection for anthropological students.

\section{Cultivation of Plants without Soil}

For many years it has been known that plants can be grown in nutrient solution eulture, without soil, provided that the medium contains the necessary elements for growth in sufficient quantity. While this method is widely used in teaching and research work, it is only recently that attempts have been made to utilize it on the commercial scale, the idea originating in the United States. Considerable interest has been aroused by the apparent success of the methods employed in the United States, and an account of their four chief methods, namely, (1) solution culture, (2) sand culture, (3) sub-irrigation, and (4) drip culture, is given in the November issue of the Journal of the Ministry of Agriculture. Experiments carried out at the Jealott's Hill Research Station to determine the results of such methods under English conditions are also described. These latter tests were confined to tomatoes, and showed that some varieties are more suited to solution culture than others. There is as yet no proof that yields are as good as those obtained under the best soil conditions; but it must be borne in mind that the method, as a commercial system, is still in its infancy. Advantages claimed for the method are the elimination of soil-borne diseases, the greater control over the type and amount of growth by judicious regulation of the culture medium, and reduction in manual labour. However, the cost of equipment is a heavy item and the technique is not yet fully worked out. The experiments are to be continued, the work being extended to other crops. The results will be awaited with interest.

\section{Smithsonian Institution Anthropological Publications}

A NEW departure in publication is a series of "Anthropological Papers" consisting of articles less extended in length than the usual report on the explorations of the Smithsonian Institution, which will be numbered consecutively, and will be collected from time to time in bulletin form as occasion requires. The first issue (Bull. $119 ; 1938$ ) contains six articles, of which the first and most considerable is a preliminary report by Mr. A. R. Kelly on the first four seasons' work of excavation on mound sites in the Ocmulgee Basin near Macon, Georgia. These excavations were undertaken originally as a measure of unemployment relief under the Civil Works Administration. The site has yielded an unanticipated wealth of material, and exploration is still in progress. Cultural development here appears, so far as present knowledge goes, to be of an extremely localized type, in which a pottery of characteristically primitive appearance is associated with an unusual type of underground house and early evidence of agriculture. Whether this represents an archaic horizon in the south-east is a moot question; but at several points it exhibits generalized resemblances with regions geographically so far distant as the Great Plains and the south-west. The remaining papers deal with a pipe ceremonial of the Arapahoes (Mr. John M. Carter), the Caribs of Dominica (Mr. Douglas Taylor), a Sauk sacred pack (Mr. Truman Michelson), the physical therapy of Soshoni of Idaho, upon which Mr. Julian H. Steward reports, and a biographical account of an Owens Valley Paiute by the same author.

\section{Scientific Publications in Japan}

A THIRD edition of a "Catalogue of Foreign Scientific Serial Publications in the Various Institutions in Japan" has just been published by the National Research Council of the Department of Education, Tokyo. The general arrangement of the work is very similar to most Union catalogues, except that whilst other publications give the holdings of each institution and an abbreviation to denote if a set is imperfect, this volume gives full particulars of the actual parts, volumes or years lacking. This feature should be of considerable service to Japanese research workers by saving them fruitless journeys, particularly as the large number of imperfections listed suggests that the proportion of incomplete 
series is somewhat high. While the method of alphabetization adopted is strictly correct, it may prove in practice to be less convenient than the 'catchword' method used in the "World List", as a research worker frequently depends upon short abbreviations, and is unacquainted with unimportant particles on which the alphabetical order depends. In addition, the adoption of a strict alphabetical sequence tends to separate periodicals dealing with the same subject, which a 'catchword' method tends to bring together. The volume is well printed in a clear type, and although the titles of the periodicals are all in languages foreign to the place of publication, the work is remarkably free from printer's errors. This catalogue affords evidence of Japanese enterprise in the field of bibliography, and it is obvious that very considerable care has been taken in its compilation. It should be of much value to scientific workers resident in Japan.

\section{The Industrial Health Research Board}

THE eighteenth annual report of the Industrial Health Research Board up to June 1938 (H.M. Stationery Office. 1s. net) contains a summary of the results of twenty years work, and describes the work of the current year. During its twenty years of activity, an attempt has been made to discover new ways and means of improving working conditions in factories and workshops, and the results of shortening the hours of labour, of splitting up shifts and of introducing rest pauses have been studied, and the influence of environmental conditions and methods of work upon the output and the health of the workers has been investigated. During the present year, the Board has investigated the relation between illumination and industrial efficiency, problems of noise and deafness, dust and ill-health, toxic solvents, work at high temperatures and ventilation. Vocational psychology applied to vocational selection and guidance in industry, vocational tests for skilled and unskilled occupations and tests of accident proneness are other subjects to which considerable attention is now being directed.

\section{Principal Earthquakes during 1937}

IN 1937 there were no really great earthquakes, but damage was done by eight shocks, and several others were felt by human beings in various parts of the world. The eight which did damage were Guelma (Algeria), February 10 ; Rabaul, $4^{\circ} 10^{\prime} \mathrm{S}$. , $152^{\circ} 10^{\prime}$ E. (New Britain), May 28; Maltrata (Mexico), July 26 ; Tsao-Tchéou (China), August 1; Manila (Philippines), August 20; Samarang (Java), September 27; Mexico City, December 23; and Oxapampa (Peru), December 29. These and others are discussed by Prof. J. P. Rothé, of Strasbourg, in Revue pour l'Étude des Calamités, 1, No. 2, 1938, under six regional headings: continent of Europe, Mediterranean region, continent of Asia, Asiatic islands and circum-Pacific coastlines, the American continent and the African continent with Madagascar. It is noteworthy that no disastrous earthquake was felt in Europe, and the only one reported from Britain was near Birmingham.

\section{The Philosophical Society}

Tнe Philosophical Society of England celebrated its silver jubilee on December 7 with a luncheon at St. Ermin's Restaurant, London, and a lecture by the Rev. I. Hartill, a vice-president of the Society, on "John Milton". Various speakers emphasized the useful purpose of the Society, its steady development and its practical achievements. Messages were sent by the American Ambassador, Lord Gorell and Prof. A. E. Heath, who were unable to attend. This Society was founded in 1913 by a group of persons interested in the moral sciences, with the view of promoting the study of philosophy among the general public. The Society publishes the Philosopher, holds meetings and organizes lectures from time to time. Also it encourages the formation of local centres and study circles, and the introduction of matters of philosophical interest in schools and other educational institutions. Its vice-presidents include many distinguished philosophers, and a number of eminent scholars from abroad are among its honorary fellows.

\section{Sir George Beilby Memorial Awards}

THE administrators of the Beilby Memorial Fund - the presidents, treasurers and secretaries of the Institute of Chemistry, the Society of Chemical Industry and the Institute of Metals respectivelyhave awarded one hundred guineas each to Dr. F. P. Bowden and Dr. Brynmor Jones. Dr. Bowden was educated at the Hutchins School, Hobart, and at the University of Tasmania. He went to Cambridge in 1927, entered Gonville and Caius College and continued electrochemical work in the laboratory of physical chemistry with Prof. E. K. Rideal and Prof. T. M. Lowry. In 1931 he was elected to a research fellowship at Caius College and was appointed University demonstrator in chemistry. In 1937 he was appointed to the Humphrey Owen Jones lectureship in physical chemistry. His electrochemical work has been mainly on over-potential and the mechanism of electro-deposition. His other work on the physical properties of surfaces has an im. portant bearing on the problems of friction, lubrication and wear. Dr. B. Jones studied metallurgy during 1919-22 at University College, Cardiff, under Prof. A. E. Read. From 1927 until 1929 he was attached to the Metallurgical Branch of the Research Department of Woolwich Arsenal, and afterwards was appointed lecturer in metallurgy at University College, Cardiff. Dr. Jones has devised many methods in metallurgical analyses. His outstanding published work has been on the subject of the nitrogen-hardening and on the heat-treatment of steels, which has been appearing in the Transactions of the Iron and Steel Institute.

\section{Physical Society's Annual Meeting}

THE twenty-ninth annual exhibition of scientific instruments and apparatus, arranged by the Physical Society, will be held at the Imperial College of Science and Technology, Imperial Institute Road, South Kensington, S.W.7, on January 3-5. The leading manufacturers of scientific instruments will be exhibit- 